\title{
Consumer Perceptions of Private Label Brands in Pakistan
}

\author{
Sana Azar, Samra Chaudary** and Ansa Mehmood ${ }^{* * *}$
}

\begin{abstract}
As the world market share of private label brands (PLBS) increases, so does the importance of and need for research in this field. Given the growing presence of PLBs in Pakistan, this study aims to examine the effects of service quality on PLB image, which we hypothesize affects purchase intention and brand loyalty. We also measure the mediating effect of perceived risk on the relationship between PLB image and purchase intention. Based on a sample of 348 respondents, we apply a structural equation model and find that (i) service quality has a positive effect on PLB image, (ii) PLB image has a positive effect on purchase intention, (iii) PLB image has a positive relationship with perceived risk, although this does not mediate the relationship between PLB image and purchase intention, and (iv) purchase intention translates positively into brand loyalty.
\end{abstract}

Keywords: private label brand image, service quality, purchase intention, brand loyalty, perceived risk.

JEL classification: M370.

\section{Introduction}

Private label brands (PLBs) - goods produced and sold by retailers - have become increasingly popular, given that consumers tend to be more loyal to stores than to brands (Ahmad, Noor \& Wel, 2014). Their performance varies by category and country (Nielsen, 2014). Globally, they generate about 15 percent of retail revenue in fast-moving consumer goods (Nielsen, 2011). Developing a PLB has become an important strategy for increasing profits (Richardson, Jain \& Dick, 1996). PLBs prove especially popular during an economic downturn, when consumer incomes fall. Such brands have an advantage in competing with national brands in terms of value for money.

\footnotetext{
${ }^{*}$ Assistant professor, Lahore School of Economics.

${ }^{* *}$ Senior teaching fellow, Lahore School of Economics.

*** Research fellow, Lahore School of Economics.
} 
PLBs are sold only by the retailer that carries those brands rather than by a national manufacturer (Burton et al., 1998). This enables retailers to create an image for their store, one that differentiates them from their competitors (Pepe, Abratt \& Dion, 2012; Hoch \& Lodish, 1998). Retailers can thus drive customer traffic in their store and create loyal customers by providing a wide product range at lower prices (Dunne \& Narasimhan, 1999). PLBs allow retailers to increase their profit margins (Ailawadi, Pauwels \& Steenkamp, 2008) by taking advantage of the built-in lower variable cost structure and higher gross margins (Pepe et al., 2012). According to Farris et al. (2006), "margins represent a key factor behind many of the most fundamental business considerations". These margins motivate retailers to add PLBs to their portfolio (Pepe et al., 2012; Ailawadi et al., 2008).

PLBs have experienced remarkable growth worldwide, growing faster than national and manufacturers' brands (Kumar \& Steenkamp, 2007). Academic research on PLBs has also grown significantly, given practitioners' increasing interest in the topic (Sethuraman, 2009). The Private Label Manufacturers Association, for instance, reports that North American consumers have welcomed the wide range of PLBs available in grocery stores and are willing to purchase these brands. ${ }^{1}$

The concept of private label branding has also increased in Pakistan, with many retailers offering products under their own names. Many small and medium manufacturers and retailers now produce specific product lines and specialize in producing store brands. Some Pakistani exporters also produce commodities for PLBs. For certain product classifications, e.g., basmati rice, a large share of Pakistan's exports to the EU consist of private label manufactures. Several large manufacturers produce for PLBs along with their own brands. Pakola, for instance, manufactures for itself as well as for Coca Cola in Pakistan (Ashraf, 2011). ${ }^{2}$

Private label branding is still a relatively new concept in Asia. While some studies have investigated consumer purchase intentions in the context of Asian markets (see Dutta \& Singh, 2014; Gupta, Jain \& Parmal,

\footnotetext{
${ }^{1}$ See www.plma.com

${ }^{2}$ Manufacturers of private label products fall into three general categories, according to the Trade Development Authority of Pakistan: (i) large manufacturers that produce both their own brands and private label products; (ii) small and medium manufacturers that specialize in particular product lines (Pakistani exporters usually fall into this category); and (iii) major retailers and wholesalers that operate their own manufacturing plants and provide private label products for their own stores (for example, Reem Rice's basmati rice processing facilities in Pakistan).
} 
2014; Ahmad et al., 2014), the bulk of the literature looks at US markets. That said, a key insight it offers is that both customers and retailers can benefit from PLBs (Koschate-Fischer, Cramer \& Hoyer, 2014).

This study contributes to the literature by extending the analysis to an emerging economy and using a structural equation model (SEM), which can test complex hypotheses. We take into account PLB image as a factor that drives the purchasing process (see Richardson, Dick \& Jain, 1994), which is rarely discussed with respect to developing economies during an economic downturn (see Semeijn, van Riel \& Ambrosini, 2004). When consumers are unfamiliar with a store brand, they employ its (perceived) image as a signal or sign in deciding whether to purchase that brand (Collins-Dodd \& Lindley, 2003; Vahie \& Paswan, 2006). Accordingly, our findings support the argument that PLB image is relevant to a developing country such as Pakistan. Moreover, Ailawadi and Keller (2004) emphasize that improving the quality of service, store atmosphere and shopping experience helps improve PLB image. Given the dearth of research on the effect of brand image and service quality in this context, we aim to link consumers' perception of quality with image development, arguing that PLB image can be improved by refining service quality.

Specifically, we ask the following questions: Does service quality affect the image of PLBs for consumers? How does PLB image affect purchase intention and, in turn, brand loyalty? Does perceived risk play a key role in mediating the impact of PLB image on purchase intention? Finally, how does purchase intention with respect to a PLB affect brand loyalty?

\section{Literature Review}

Service quality reflects a consumer's evaluation of different attributes of quality, including interaction, physical environment and outcome (Zehir et al., 2011). It indicates the gap between what $\mathrm{s} /$ he expects of the service and what $s$ /he receives (Parasuraman, Zeithaml \& Berry, 1985; Lewis \& Booms, 1983; Crosby, 1979). Service quality also refers to the level of service accessed through the relationship and communication between a service provider and a consumer. Grönroos (1984) divides this into technical quality (what is done) and functional quality (how it is done).

In the case of PLBs, good service quality leads to greater satisfaction with the store concerned (Anderson, Fornell \& Lehmann, 1994; Carrillat, Jaramillo \& Mulki, 2009; Parasuraman et al., 1985). Thus, when consumers 
form a good impression of a store, based on the quality of service it offers, they instantly create a positive PLB image. This level of customer satisfaction with the store makes the buying decision easier. Huang (2003) applies this concept to the banking industry and shows that the quality of service provided by a bank has a substantial impact on its image. Lin (2005) traces a similar relationship between good service quality, customer satisfaction, brand loyalty and brand image. $\mathrm{Wu}$, Yeh and Hsiao (2011) test the relationship between service quality and PLB image and find that it is positive and significant. Based on the literature, we present the following hypothesis (H1): service quality has a positive effect on PLB image.

Numerous studies support the positive relationship between store image and purchase intention (see Rehman et al., 2014; Ahmad et al., 2014). The concept of store image was introduced by Martineau (1958), who observed that consumer perception of a store pertained to its functional qualities and emotional factors. This definition has been extended to include other store attributes considered essential by shoppers (Wu et al., 2011; James, Durand \& Dreves, 1976). Store image encompasses not only the physical environment of a store (Richardson et al., 1996), but also what customers think of its products and quality of service (Zimmer \& Golden, 1988). Purchase intention refers to the likelihood of a given product being consumed in the future. Thus, if a consumer's purchase intention increases, so does the possibility that $\mathrm{s} /$ he will purchase that product (Dodds, Monroe \& Grewal, 1991; Schiffman \& Kanuk, 2007).

A positive brand image is associated with greater intention to buy (Dodds et al., 1991; Grewal et al., 1998). Consumers with a high store image will perceive its product quality as being superior. Thus, image has a positive influence over purchase intention with respect to that retailer (Grewal et al., 1998). Analogously, PLB image is the association that consumers attach to PLB products, which drives their perception and opinion of that brand (Wu et al., 2011). Ahmad et al. (2014) argue that PLB image affects purchase intention. Thus, our second hypothesis (H2) is that PLB image has a positive effect on purchase intention.

While purchase intention refers to the likelihood that a consumer will buy a given product in the future, Diallo (2012) and Jacoby and Chestnut (1978) define brand loyalty as the consumer's tendency to purchase a service or product of a specific brand again and again. Brand loyalty includes the customer's commitment to re-buy the same brand or speak about it positively to others (Gogoi, 2013). In this sense, it helps determine a company's effectiveness and profitability (Aaker, 1991). 
Several studies show that brand loyalty extends to PLBs. Our third hypothesis (H3) is that purchase intention has a positive impact on brand loyalty.

Unlike national brands, PLB products tend to advertise less and thus less information is passed onto the consumer. Consumers use various external cues - including brand image and service quality - to reduce the perceived risk associated with PLB products (Shimp \& Bearden, 1982; Perry \& Perry, 1976). When brand image improves in a consumer's eyes, the perceived risk decreases (Cox, 1962; Kotler \& Keller, 2008; Roselius, 1971). Perceived risk is measured as the financial, physical and functional risk associated with using a given product (Stone \& Grønhaug, 1993). Liljander, Polsa \& van Riel (2009) show that it can have an adverse impact on the image of the PLB. As argued above, stores can improve their PLB image and use it to differentiate themselves from other stores, build customer loyalty and thus increase their profits (Hoch, 1996; Levy \& Weitz, 2004; Richardson et al., 1996). This points to a negative and significant relationship between PLB image and perceived risk (Wu et al., 2011; Rzem \& Debabi, 2012). Thus, our fourth hypothesis (H4) is that PLB image has a negative effect on perceived risk.

Finally, perceived risk is an essential factor in making purchase decisions with respect to PLBs (Wu et al., 2011; Dursun et al., 2011; Diallo, 2012; Yap, Leong \& Wee, 2012). The higher the risk associated with a brand (in this case, a PLB), the lower will be the consumer's purchase intention (Tseng \& Hwang, 2003). In the same way, smaller levels of perceived risk imply greater intention to purchase a PLB product (Narasimhan \& Wilcox, 1998; Shimp \& Bearden, 1982; Taylor, 1974). Given that the mediating role of risk has received little attention in the context of PLBs, our fifth hypothesis (H5) is that perceived risk mediates the relationship between PLB image and purchase intention.

Figure 1 illustrates the hypotheses discussed above.

Figure 1: Theoretical framework

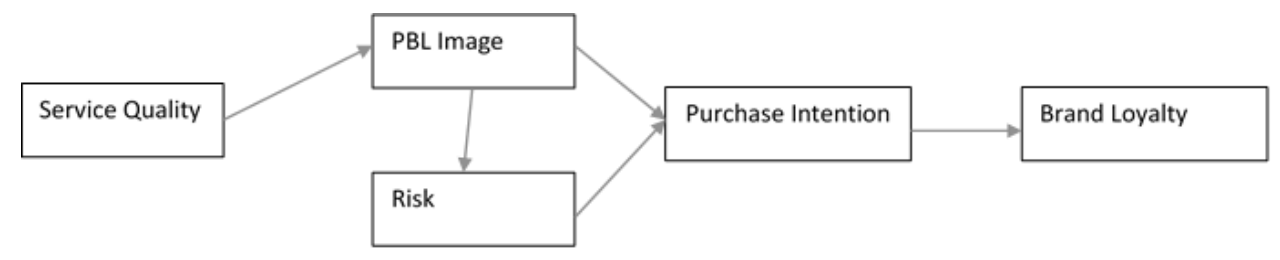




\section{Data and Methodology}

Our sample consisted of young university students as potential PLB consumers. Employing convenience and snowball sampling, we distributed 500 questionnaires in English that could be completed online or on paper. The final usable sample comprised 348 questionnaires, resulting in a response rate of 69.6 percent. A t-test was conducted to compare early and late respondents (see Miller \& Smith, 1983). Responses were compared with each item of the instrument to determine the nonresponse error (see Gall, Borg \& Gall, 1996). No significant differences were noted for any item. The questionnaires contained measurement items and sociodemographic questions (see Appendix).

\subsection{Instruments}

Table 1 summarizes the operational definition of each variable used in the analysis.

Service quality consists of a five-item scale measuring three dimensions: interaction quality, service environment quality and outcome quality (see Brady \& Cronin, 2001). Interaction quality reflects customers' perception of their interaction with the salesperson. Service environment takes into account their evaluation of the store environment. Outcome quality gauges their purchase experience in that store.

Table 1: Measures used in the study

\begin{tabular}{lcl}
\hline Variable & Number of items & \multicolumn{1}{c}{ Study } \\
\hline Service quality & 5 & Brady and Cronin (2001) \\
Purchase intention & 2 & Grewal et al. (1998) \\
& 2 & Liljander et al. (2009) \\
& 2 & Knight and Kim (2007) \\
PLB image & 5 & Vahie and Paswan (2006) \\
Perceived risk & 2 & Mieres et al. (2006) \\
& 4 & Stone and Gronhaug (1993) \\
Brand loyalty & 4 & Vogel et al. (2008), Dwivedi et al. (2012) \\
& 1 & Kuenzel and Halliday (2008) \\
\hline
\end{tabular}

PLB image is measured as a two-dimensional construct that includes affection and quality (see Keller, 2003). Affection refers to the customer's satisfaction with, or inclination toward, a given PLB. Quality refers to the customer's perception of the product's quality. Vahie and Paswan (2006) measure PLB image using five items. 
Perceived risk is gauged by three dimensions: financial risk, functional risk and physical risk. The physical and functional risk measures are adapted from Stone and Grønhaug (1993). Functional risk denotes the possibility that the product will not achieve its intended function. Physical risk refers to the possibility that the product might cause physical harm. The measures of financial risk are adapted from Mieres, Martin and Gutierrez (2006). Financial risk refers to the possibility that the product's price exceeds the benefit or value received by the consumer. Six items are used to measure these three dimensions of perceived risk.

Purchase intention is measured using a two-item scale developed by Knight and Kim (2007). The other four items are adapted from Grewal et al. (1998) and Liljander et al. (2009). Loyalty intentions are operationalized using five items: two adapted from Vogel, Evanschitzky and Ramaseshan (2008), two adapted from Dwivedi et al. (2012) and one adapted from Kuenzel and Halliday (2008).

\subsection{Methodology}

The SEM is run using Amos 18. The benchmark for all factor loadings is 0.5 (see $\mathrm{Wu}$ et al., 2011). Any item with a factor loading of below 0.5 is discarded. The composite reliability (CR) of the constructs is tested using the standardized confirmatory factor analysis (CFA) solutions (see Shook et al., 2004) and a benchmark of 0.7 (see Diallo, 2012). The data is also examined for convergent and discriminant validity. The measures of model fit reported include the root mean square error of approximation (RMSEA) and chi-square divided by the degrees of freedom (CMIN/df).

The incremental fit indices include the normed fit index (NFI), nonnormed fit index (NNFI or TLI), comparative fit index (CFI) and incremental fit index (IFI). These show that our model fits the data well. All the model fits mentioned above are also reported in the path analysis. The squared multiple correlation (R2) is also calculated to gauge the variable's explanatory power. The extent of mediation is also tested using an SEM, following Iacobucci (2008) and Zhao, Lynch and Chen (2010). We do not use Baron and Kenny's approach, given the criticism put forward by MacKinnon, Fairchild and Fritz (2007).

\section{Descriptive Analysis}

Respondents were asked to report their age, gender, monthly income, level of education, student status, marital status and place of 
residence. The sample comprised 55.7 percent of women and 44.3 percent of men. Most respondents were 20-25 years old (81.9 percent), 93.7 percent were single and 84.8 percent were students, 76.4 percent of whom were undergraduates. More than half the sample resided in Lahore (55 percent), followed by Sialkot ( 35 percent) and other areas ( 5 percent).

The skewness and kurtosis values lie within the benchmark \pm 2.0 . Harman's (1967) single-factor test confirms that the variance explained by each variable is not greater than 60 percent. The results show that the first component explains 53.55 percent of the variance.

\subsection{Measurement Model}

The CFA results show that the model fit is acceptable. Two items measuring perceived risk and PLB image - are deleted, as their factor loadings are below 0.5 . The factor loadings of the remaining items range between 0.60 and 0.95 , as shown in Table 2 . The CR values range between 0.808 and 0.936. All the variables used exhibit a reasonable degree of reliability. The table also gives the convergent validity of the data, which is gauged through average variance extracted (AVE) and discriminant validity (DV).

Table 2: Results of measurement model

\begin{tabular}{llcccc}
\hline Variable & Items & Factor loading & CR & AVE & DV \\
\hline Purchase intention & P1 & 0.88 & 0.935 & 0.708 & 0.842 \\
& P2 & 0.89 & & & \\
& P3 & 0.92 & & & \\
P4 & 0.88 & & & \\
Service quality & P5 & 0.72 & & & \\
& P6 & 0.75 & & & \\
& SQ1 & 0.75 & 0.930 & 0.727 & 0.853 \\
& SQ2 & 0.89 & & & \\
PLB image & SQ3 & 0.87 & & & \\
& SQ4 & 0.94 & & & \\
Perceived risk & SQ5 & 0.81 & & & \\
& PLBI1 & 0.95 & 0.808 & 0.592 & 0.769 \\
& PLBI2 & 0.69 & & & \\
& PLBI3 & 0.63 & & & \\
& PR2 & 0.60 & 0.849 & 0.591 & 0.769 \\
& PR3 & 0.75 & & & \\
\hline
\end{tabular}




\begin{tabular}{llcccc}
\hline Variable & Items & Factor loading & CR & AVE & DV \\
\hline \multirow{3}{*}{ Brand loyalty } & PR5 & 0.73 & & & \\
& BL1 & 0.87 & 0.936 & 0.747 & 0.864 \\
& BL2 & 0.85 & & & \\
& BL3 & 0.82 & & & \\
& BL4 & 0.83 & & & \\
& BL5 & 0.94 & & & \\
\hline
\end{tabular}

Source: Authors' calculations.

Model fit indices are divided into standalone and incremental fit indices (Bollen, 1989). To evaluate the measurement model fit, we use the following indices: CFI, TLI, NFI, CMIN/DF, IFI and RMSEA. The absolute and incremental model fit indices indicate that the proposed model fits the data well (Table 3). All the indices used are deemed acceptable, following Zarei et al. (2013).

Table 3: Goodness-of-fit model (CFA)

\begin{tabular}{lcc}
\hline Index & Model fit value & Standard value \\
\hline Standalone indices & & \\
CMIN/d.f. & 4.36 & Range (1 to 5) \\
RMSEA & 0.03 & $\leq 0.05$ \\
Incremental indices & & \\
$\quad$ Normed fit index (NFI) & 0.92 & $\geq 0.90$ \\
Non-normed fit index (NNFI or TLI) & 0.98 & $\geq 0.90$ \\
Comparative fit index (CFI) & 0.93 & $\geq 0.90$ \\
Incremental fit index (IFI) & 0.91 & $\geq 0.90$ \\
\hline
\end{tabular}

Source: Authors' calculations.

\subsection{Path Analysis (Structural Model)}

Table 4 summarizes the results of the structural model, including levels of significance. The parameter estimates give the magnitude and sign of the relationship between constructs. Table 5 shows that the goodness-of-fit values lie within acceptable ranges, indicating that the model fits the data.

$\mathrm{H} 1$ tests the relationship between service quality and PLB image. The model yields an estimate of 0.408 ( $\mathrm{p}$-value $<0.05$ ), indicating that a one-unit increase in service quality increases PLB image by 0.408 units (implying a positive relationship). We test $\mathrm{H} 2$ by regressing PLB image on purchase intention. This yields a coefficient of 0.634 ( $\mathrm{p}$-value $<0.05)$, 
indicating that PLB image has a positive impact on purchase intention. H3 tests the relationship between purchase intention and brand loyalty. We obtain a coefficient of 0.78 , indicating a positive and highly significant relationship between the two variables. $\mathrm{H} 4$ proposes a negative relationship between PLB image and perceived risk. We find that the relationship is highly significant, with a negative coefficient value of 0.459 . As expected, a positive image reduces consumers' perceived risk.

Table 4: Results of structural model (structural coefficients)

\begin{tabular}{lccc}
\hline Hypothesized path & R2 & Estimate & $\begin{array}{c}\text { Significanc } \\
\text { e }\end{array}$ \\
\hline H1: Service quality ---> PLB image & 0.06 & 0.408 & $* * *$ \\
H2: PLB image ---> purchase intention & 0.62 & 0.634 & $* * *$ \\
H3: Purchase intention ---> brand & 0.69 & 0.780 & $* * *$ \\
loyalty & & & \\
H4: PLB image ---> perceived risk & 0.43 & -0.496 & $* * *$ \\
\hline
\end{tabular}

Source: Authors' calculations.

Table 5: Results of goodness-of-fit model (path analysis/structural model)

\begin{tabular}{lcc}
\hline Index & Model fit value & Standard value \\
\hline Standalone indices & & \\
CMIN/d.f. & 3.11 & Range (1 to 5) \\
RMSEA & 0.01 & $\leq 0.1$ \\
Incremental indices & & $\geq 0.9$ \\
$\quad$ Normed fit index (NFI) & 0.95 & $\geq 0.9$ \\
Non-normed fit index (NNFI or TLI) & 0.98 & $\geq 0.9$ \\
Comparative fit index (CFI) & 0.94 & $\geq 0.9$ \\
Incremental fit index (IFI) & 0.95 & \\
\hline
\end{tabular}

Source: Authors' calculations.

The squared multiple correlation term (R2) denotes the explanatory power of the variable. In this case, the $\mathrm{R} 2$ values for service quality and PLB image are very low (0.06). However, the overall model appears to be satisfactory. This anomaly may be due to the large variation across individual units of observation (an inherent characteristic of crosssectional data). Another reason may be that the survey questionnaire was in English, possibly compromising respondents' ability to communicate. $\mathrm{Hu}$ et al. (1999) note that low R2 values suggest that other factors be added to the model. 


\subsection{Mediating Effects}

The mediating effects were tested by bootstrapping in Amos 18 (see Zhao et al., 2010). Table 6 gives the p-values for the mediating effect of perceived risk on the relationship between PLB image and purchase intention. Although the two variables have a direct relationship with each other, this relationship is not significant in the presence of perceived risk. Thus, we reject $\mathrm{H} 5$ on finding that perceived risk does not mediate the relationship between PLB image and purchase intention.

Table 6: Testing for mediating effects

\begin{tabular}{lcccc}
\hline $\begin{array}{l}\text { Mediation } \\
\text { hypothesis }\end{array}$ & $\begin{array}{c}\text { Direct effect } \\
\text { (without } \\
\text { mediation) }\end{array}$ & $\begin{array}{c}\text { Direct effect } \\
\text { (with } \\
\text { mediation) }\end{array}$ & $\begin{array}{c}\text { Indirect effect } \\
\text { (with } \\
\text { mediation) }\end{array}$ & Result \\
\hline $\begin{array}{l}\text { H5: PLBI --> } \\
\text { PR --> PI }\end{array}$ & 0.009 & 0.020 & 0.365 & No mediation \\
\hline
\end{tabular}

Source: Authors' calculations.

\section{Discussion}

This study evaluates consumer perceptions of store brands (PLBs) in Pakistan by determining which factors affect consumers' purchase intentions. We find that PLB image has a positive impact on purchase intention. This is consistent with studies such as Dodds et al. (1991), Grewal et al. (1998) and Faryabi, Sadeghzadeh and Saed (2012).

Service quality is found to have a direct and positive effect on PLB image. This implies that, when consumers receive a high level of service at a given store, their satisfaction levels will increase and they will be more likely to speak about the store in positive terms - thereby improving the image of the private brands it offers. Lin (2005) and Wu et al. (2011) also report a positive relationship between service quality and brand image. By providing a higher level of service to its customers, a store can outperform other retailers and remain competitive. This translates into greater purchase intention on the part of its customers and higher brand loyalty to its PLBs. Service quality thus acts as a predictor of consumers' purchase intentions with respect to PLBs.

In terms of the association between PLB image and perceived risk, the results of the path analysis indicate a significant negative relationship between the two variables. This implies that consumers with a positive 
image of a given PLB (in terms of quality and value for money) will likely associate less risk with it. PLBs are also perceived as being risky and inexpensive, implying that people are less willing to buy them. Our sample of consumers is reasonably well off, which could explain why respondents preferred to buy national or international brands rather than store brands, which they deemed more risky.

Finally, we test the relationship between purchase intention and brand loyalty. We find that consumers who are satisfied with a given purchase will likely return to buy other products, thereby becoming loyal to that brand in the future.

The study's findings have several useful marketing implications that underscore the use of PLBs as a critical strategy for retailers. Many items, including grocery products, are now perceived as commodities. As consumers become more aware, their interest has begun to shift from national to store brands. In this context, the role and importance of supermarkets, hypermarkets and grocery stores is increasing, with such outlets now offering a greater variety of clearly labeled, store-branded products. By reducing the element of risk associated with store brands and building greater trust with their customers (for instance, by improving service quality), stores can increase their consumer loyalty to the PLBs they offer.

\section{Limitations and Future Research}

Our results should be interpreted in the context of several limitations, which in turn reflect avenues for further research:

- The sample consisted primarily of young, educated, urban respondents. This implies that our findings cannot necessarily be generalized.

- Unlike other studies, we have not concentrated on specific types of stores such as drugstores or grocery stores. Wu et al. (2011), for instance, look at specific industries to examine how PLB image affects purchase intention. Future research could consider the influence of other product-level characteristics such as retail competitiveness, shelf space used and product variety.

- We found no evidence of perceived risk mediating the relationship between PLB image and purchase intention. This could be a location- 
specific result. Future research could thus reapply this hypothesis to a particular industry.

- Brand loyalty does not necessarily apply to all consumers, especially in Pakistan, where poverty and inflation may force them to change their purchasing patterns. The fall in consumer purchasing power means that people prefer cheaper products.

\section{Conclusion}

The aim of this study was to assess the relationship between service quality and PLB image to determine which factors increase purchase intention with respect to PLBs. We applied an SEM to a sample of 348 respondents to measure the attributes of purchase intention. Using CFA and path analysis applied through Amos 18 and SPSS, we measured the validity and reliability of the constructs, gauged the model fit and tested our hypotheses.

Consistent with the literature, we find that (i) service quality and PLB image are positively correlated, (ii) PLB image is positively correlated with buying intent, and (iii) the retailer's service quality has a positive impact on PLB image and increases purchase intention. PLB image is, therefore, an important determinant of purchase intention. Better service quality is likely to increase PLB image, resulting in higher consumer loyalty via purchase intention. 


\section{References}

Aaker, D. A. (1991). Managing brand equity. New York: Free Press.

Ahmad, A., Noor, S. M., \& Wel, C. A. C. (2014). Factors influencing consumers' purchase decision of private label brand products. International Journal of Economic Practices and Theories, 4(2), 101-110.

Ailawadi, K. L., \& Keller, K. L. (2004). Understanding retail branding: Conceptual insights and research priorities. Journal of Retailing, 80(4), 331-342.

Ailawadi, K. L., Pauwels, K., \& Steenkamp, J.-B. E. M. (2008). Private-label use and store loyalty. Journal of Marketing, 72(6), 19-30.

Anderson, E. W., Fornell, C., \& Lehmann, D. R. (1994). Customer satisfaction, market share, and profitability: Findings from Sweden. Journal of Marketing, 58(3), 53-66.

Ashraf, M. (2011). Vibrant Pakistan: Your private label source. Retrieved from https://www.tdap.gov.pk/doc_reports/tdap_report_on_plma_20 11.pdf

Bollen, K. A. (1989). Structural equations with latent variables. New York: Wiley.

Brady, M. K., \& Cronin, J. J. (2001). Some new thoughts on conceptualizing perceived quality: A hierarchical approach. Journal of Marketing, 65(3), 34-49.

Burton, S., Lichtenstein, D. R., Netemeyer, R. G., \& Garretson, J. A. (1998). A scale for measuring attitude toward private label products and an examination of its psychological and behavioral correlates. Journal of the Academy of Marketing Science, 26(4), 293-306.

Carrillat, F. A., Jaramillo, F., \& Mulki, J. P. (2009). Examining the impact of service quality: A meta-analysis of empirical evidence. Journal of Marketing Theory and Practice, 17(2), 95-110.

Collins-Dodd, C., \& Lindley, T. (2003). Store brands and retail differentiation: The influence of store image and store brand attitude on store own brand perceptions. Journal of Retailing and Consumer Services, 10(6), 345-352. 
Cox, D. F. (1962). The measurement of information value: A study in consumer decision-making. In W. S. Decker (ed.), Emerging concepts in marketing. Chicago: American Marketing Association.

Crosby, P. B. (1979). Quality is free: The art of making quality certain. New York: McGraw-Hill.

Diallo, M. F. (2012). Effects of store image and store brand price-image on store brand purchase intention: Application to an emerging market. Journal of Retailing and Consumer Services, 19(3), 360-367.

Dodds, W. B., Monroe, K. B., \& Grewal, D. (1991). Effects of price, brand, and store information on buyers' product evaluations. Journal of Marketing Research, 28(3), 307-319.

Dunne, D., \& Narasimhan, C. (1999). The new appeal of private labels. Harvard Business Review, May-June, 41-52.

Dursun, İ., Kabadayi, E. T., Alan, A. K., \& Sezen, B. (2011). Store brand purchase intention: Effects of risk, quality, familiarity and store brand shelf space. Procedia - Social and Behavioral Sciences, 24, 1190-1200.

Dutta, K., \& Singh, S. (2014). Deriving customer satisfaction and loyalty from organized retailer's sales promotion activities in India. International Journal of Sales, Retailing and Marketing, 3(1), 21-32.

Dwivedi, A., Merrilees, B., Miller, D., \& Herington, C. (2012). Brand, value and relationship equities and loyalty-intentions in the Australian supermarket industry. Journal of Retailing and Consumer Services, 19(5), 526-536.

Farris, P. W., Bendle, N. T., Pfeifer, P. E., \& Reibstein, D. J. (2006). Marketing metrics: 50+ metrics every executive should master. London: Pearson Education.

Faryabi, M., Sadeghzadeh, K., \& Saed, M. (2012). The effect of price discounts and store image on consumer's purchase intention in online shopping context case study: Nokia and HTC. Journal of Business Studies Quarterly, 4(1), 197-205.

Gall, M. D., Borg., W. R., \& Gall, J. P. (1996). Educational research: An introduction. London: Pearson. 
Gogoi, B. J. (2013). Study of antecedents of purchase intention and its effect on brand loyalty of private label brand of apparel. International Journal of Sales and Marketing Management Research and Development, 3(2), 73-86.

Grewal, D., Krishnan, R., Baker, J., \& Borin, N. (1998). The effect of store name, brand name and price discounts on consumers' evaluations and purchase intentions. Journal of Retailing, 74(3), 331-352.

Grönroos, C. (1984). A service quality model and its marketing implications. European Journal of Marketing, 18(4), 36-44.

Gupta, S., Jain, R., \& Parmal, V. (2014). Study of impact of brand image of retailers on customers' buying decision of store brands. International Journal of Sales, Retailing and Marketing, 3(1), 3-10.

Harman, H. (1967). Modern factor analysis. Chicago, IL: University of Chicago Press.

Hoch, S. J. (1996). How should national brands think about private labels? Sloan Management Review, 37(2), 89-102.

Hoch, S. J., \& Lodish, L. M. (1998). Store brands and category management. Unpublished manuscript, Wharton School, University of Pennsylvania, PA.

Hu, P. J., Chau, P. Y. K., Sheng, O. R. L., \& Tam, K. Y. (1999). Examining the technology acceptance model using physician acceptance of telemedicine technology. Journal of Management Information Systems, 16(2), 91-112.

Huang, M. C. (2003). A study on service quality, enterprise image and consumer loyalty of banks in Taiwan. Unpublished Master's thesis, Nanhua University, Taiwan.

Iacobucci, D. (2008). Mediation analysis. Thousand Oaks, CA: SAGE.

Jacoby, J., \& Chestnut, R. W. (1978). Brand loyalty: Measurement and management. New York: Wiley.

James, D. L., Durand, R. M., \& Dreves, R. A. (1976). The use of a multiattribute attitude model in a store image study. Journal of Retailing, 52(2), 23-32. 
Keller, K. L. (2003). Strategic brand management: Building, measuring, and managing brand equity (2nd ed.). Upper Saddle River, NJ: Prentice Hall.

Knight, D. K., \& Kim, E. Y. (2007). Japanese consumers' need for uniqueness: Effects on brand perceptions and purchase intention. Journal of Fashion Marketing and Management, 11(2), 270-280.

Koschate-Fischer, N., Cramer, J., \& Hoyer, W. D. (2014). Moderating effects of the relationship between private label share and store loyalty. Journal of Marketing, 78(2), 69-82.

Kotler, P. T., \& Keller, K. L. (2008). Marketing management (13th ed.). Upper Saddle River, NJ: Prentice-Hall.

Kuenzel, S., \& Halliday, S. V. (2008). Investing antecedents and consequences of brand identification. Journal of Product and Brand Management, 17(5), 293-304.

Kumar, N., \& Steenkamp, J.-B. E. M. (2007). Private label strategy: How to meet the store brand challenge. Boston, MA: Harvard Business School.

Levy, M., \& Weitz, B. A. (2004). Retailing management (5th ed.). New York: McGraw-Hill.

Lewis, R. C., \& Booms, B. H. (1983). The marketing aspect of service quality. In L. Berry, G. Shostack \& G. Upah (eds.), Emerging perspectives on services marketing (pp. 99-107). Chicago, IL: American Marketing Association.

Liljander, V., Polsa, P., \& van Riel, A. (2009). Modeling consumer responses to an apparel store brand: Store image as a risk reducer. Journal of Retailing and Consumer Services, 16(4), 281-290.

Lin, C. T. (2005). A study on the relationship among service quality, enterprise image, customer satisfaction and consumer loyalty of banks. Unpublished Master's thesis, Chaoyang University of Technology, Taiwan.

MacKinnon, D. P., Fairchild, A. J., \& Fritz, M. S. (2007). Mediation analysis. Annual Review of Psychology, 58, 593-614. 
Martineau, P. (1958). The personality of the retail store. Harvard Business Review, 36, 47-55.

Mieres, C. G., Martin, A. M. D., \& Gutierrez, J. A. T. (2006). Antecedents of the difference in perceived risk between store brands and national brands. European Journal of Marketing, 40(1-2), 61-82.

Miller, L. E., \& Smith, K. L. (1983). Handling nonresponse issues. Journal of Extension, 21(5), 45-50.

Narasimhan, C., \& Wilcox, R. T. (1998). Private labels and the channel relationship: A cross-category analysis. Journal of Business, 71(4), 573-600.

Nielsen. (2011). The rise of the value-conscious shopper. Available at http://hk. nielsen.com/documents/PrivateLabelGlobalReport.pdf

Nielsen. (2014). The state of private label around the world. Available at http://www.nielsen.com/content/dam/nielsenglobal/kr/docs/gl obal-report/2014/Nielsen Global Private Label Report November 2014.pdf

Parasuraman, A., Zeithaml, V. A., \& Berry, L. L. (1985). A conceptual model of service quality and its implications for future research. Journal of Marketing, 49(4), 41-50.

Pepe, M. S., Abratt, R., \& Dion, P. (2012). Competitive advantage, privatelabel brands, and category profitability. Journal of Marketing Management, 28(1-2), 154-172.

Perry, M., \& Perry, A. (1976). Service contract compared to warranty as a means to reduce consumer's risk. Journal of Retailing, 52, 33-40.

Rehman, H. I., Ashar, M., Javed, B., Khalid, M., \& Nawaz, R. (2014). Impact of retail store characteristics on purchase intention. International Journal of Sales, Retailing and Marketing, 3(1), 11-20.

Richardson, P. S., Dick, A. S., \& Jain, A. K. (1994). Extrinsic and intrinsic cue effects on perceptions of store brand quality. Journal of Marketing, 58(4), 28-36.

Richardson, P. S., Jain, A. K., \& Dick, A. S. (1996). Household store brand proneness: A framework. Journal of Retailing, 72(2), 159-185. 
Roselius, T. (1971). Consumer rankings of risk reduction methods. Journal of Marketing, 35(1), 56-61.

Rzem, H., \& Debabi, M. (2012). Store image as a moderator of store brand attitude. Journal of Business Studies Quarterly, 4(1), 130-148.

Schiffman, L. G., \& Kanuk, L. L. (2007). Consumer behavior (9th ed.). Upper Saddle River, NJ: Prentice Hall.

Semeijn, J., van Riel, A. C. R., \& Ambrosini, A. B. (2004). Consumer evaluations of store brands: Effect of store image and product attributes. Journal of Retailing and Consumer Services, 11(4), 247-258.

Seock, Y.-K., \& McBride, J. (2017). Influence of department store image on private label brand preference among consumers with different level of knowledge and familiarity. In C. L. Campbell (ed.), The customer is NOT always right? Marketing orientations in a dynamic business world (pp. 96-98). Berlin: Springer.

Sethuraman, R. (2009). Assessing the external validity of analytical results from national brand and store brand competition models. Marketing Science, 28(4), 759-781.

Shimp, T. A., \& Bearden, W. O. (1982). Warranty and other extrinsic cue effects on consumers' risk perceptions. Journal of Consumer Research, 9(1), 38-46.

Shook, C. L., Ketchen, Jr, D. J., Hult, G. T. M., \& Kacmar, K. M. (2004). An assessment of the use of structural equation modeling in strategic management research. Strategic Management Journal, 25(4), 397-404.

Stone, R. N., \& Grønhaug, K. (1993). Perceived risk: Future considerations for the marketing discipline. European Journal of Marketing, 27(3), 39-50.

Taylor, J. W. (1974). The role of risk in consumer behavior. Journal of Marketing, 38(2), 54-60.

Tseng, Y. M., \& Hwang, F. S. (2003). The mediate effect of price consciousness on purchasing private brand: The application of path analysis model. Chiao Da Management Review, 23(1), 151-182. 
Vahie, A., \& Paswan, A. (2006). Private label brand image: Its relationship with store image and national brand. International Journal of Retail and Distribution Management, 34(1), 67-84.

Vogel, V., Evanschitzky, H., \& Ramaseshan, B. (2008). Customer equity drivers and future sales. Journal of Marketing, 72(6), 98-108.

Wu, P. C., Yeh, G. Y.-Y., \& Hsiao, C.-R. (2011). The effect of store image and service quality on brand image and purchase intention for private label brands. Australasian Marketing Journal, 19(1), 30-39.

Yap, S.-F., Leong, S.-M., \& Wee, Y.-G. (2012). Store brand proneness: Effects of perceived risks, quality and familiarity. Australasian Marketing Journal, 20(1), 48-58.

Zarei, E., Zainalipour, H., Mohammadi, M., \& Zare, S. (2013). Scale construction and validation for evaluation of training performance in Hormozgan University of Medical Science, Iran. Journal of Applied Environmental and Biological Sciences, 3(12), 101-106.

Zehir, C., Sahin, A., Kitapci, H., \& Ozsahin, M. (2011). The effects of brand communication and service quality in building brand loyalty through brand trust: The empirical research on global brands. Procedia - Social and Behavioral Sciences, 24, 1218-1231.

Zhao, X., Lynch, J. G., \& Chen, Q. (2010). Reconsidering Baron and Kenny: Myths and truths about mediation analysis. Journal of Consumer Research, 37(2), 197-206.

Zimmer, M. R., \& Golden, L. L. (1988). Impressions of retail stores: A content analysis of consumer images. Journal of Retailing, 64(1), 265-293. 
Appendix

The following items were used to measure the study's variables and factors affecting purchase intention. Items marked with an asterisk were deleted from the study because they had lower factor loadings.

Service quality (Brady \& Cronin, 2001):

- I would say that the quality of my interaction with this store's employees is high.

- I would rate this store's physical environment highly.

- I always have an excellent experience when I visit this store.

- I feel good about what this store provides its customers.

- I would say that the store's physical environment is one of the best in the industry.

Purchase intention (Grewal et al., 1998; Liljander et al., 2009; Knight \& Kim, 2007):

- The probability that I would consider buying store brands is high.

- I will purchase store brands next time.

- I would consider buying store brands.

- There is a strong likelihood that I will buy store brands.

- I intend to buy this store's private label brand frequently.

- I plan to buy this store's private label brand more often.

PLB image (Vahie \& Paswan, 2006):

- Too many of the private label brands I buy at this store are defective in some way.

- Most private label brands I buy at this store wear out too quickly.

- This store does not care enough about the quality of its private label brand.

- I like this store's private label brand very much*.

- I am satisfied with most of the private label brands I buy at this store*. 
Perceived risk (Mieres et al., 2006):

- I think that buying this store brand is a waste of money and I am worried that it is not worth the money spent*.

- I think that buying a store brand is not a wise way of spending money.

Perceived risk, modified (Stone \& Gronhaug, 1993):

- Since private label brands are not safe, if I purchase a private label brand product, I would be concerned about the potential physical risk associated with this product.

- Using this product will lead to some uncomfortable physical sideeffects.

- If I purchase a private label brand for use, I become concerned that the product will not provide the level of benefits I expect.

- I am concerned about the reliability and dependability of the product I purchase from a private label brand for use*.

Brand loyalty (Vogel et al., 2008; Dwivedi et al., 2012; Kuenzel \& Halliday, 2008):

- I would continue to repurchase from this brand.

- I would recommend this store to my friends and family.

- I would buy additional products from this brand.

- I would spend more than a year on this store brand.

- I will speak positively about store brands. 